\title{
THE ILLUSORY TRUST DOCTRINE: FORMAL OR SUBSTANTIVE?
}

\author{
Mark Bennett*
}

"A document is put before us. Does it or does it not create a trust?"1

\section{INTRODUCTION}

The concepts of form and substance exist in a variety of legal contexts, but they sometimes mean something slightly different in each one. ${ }^{2}$ When deploying the terms "form" and "substance", care must therefore be taken to identify precisely the concept that one wishes to use. In several recent decisions considering basic principles of trusts law, Commonwealth courts have used this language without such precision. One way of using the concepts of form and substance in trusts law is to say that despite a person using the form of the trust, in the sense of the language and usual clauses found in a trust deed, they have not created an arrangement that has the substance of a trust. In the 2017 English trusts law decision, JSC Mezhdunarodniy Promyshlenniy Bank $v$ Pugachev, ${ }^{3}$ Birss J concluded that "[i]n substance the deeds allow Mr Pugachev to retain his beneficial ownership of the assets", ${ }^{4}$ which meant that they did not constitute a trust. This has been spoken of as the "true effect of the trusts" claim, or as an assertion that the trust is "illusory". I will refer to this as the illusory trust doctrine (ITD).

* Faculty of Law, Victoria University of Wellington. Thank you to Cate Barnett and Lucy Kenner for research assistance related to this article, and to them and Tobias Barkley and Matthew Harding, Geoff McLay and the participants in a session at the Obligations IX Conference, Melbourne 2018 for comments on earlier drafts of this article.

1 FW Maitland Equity: A Course of Lectures (Cambridge University Press, Cambridge, 1910) at 36-37.

2 Indeed, in a recent article on the important concepts of form and substance in the law, only one of the two concepts identified tracks the uses discussed in this article: see Matti Ilmari Niemi "Form and Substance in Legal Reasoning: Two Conceptions" (2010) 23 Ratio Juris 479. See also Kit Barker "Form and Substance: Three Observations on the State of Debate" in Andrew Robertson and James Goudkamp (eds) Form and Substance in the Law of Obligations (Hart Publishing, Oxford, 2019) 433 at 434-436.

3 JSC Mezhdunarodniy Promyshlenniy Bank v Pugachev [2017] EWHC 2426 (Ch).

4 At [278]. 
The ITD inquiry asks whether any of the terms of the trust deed individually, or in combination with each other, deprive the arrangement of a necessary or "core" feature of the trust. Possible core trust features include the trustee having enforceable fiduciary obligations to the beneficiaries, and the settlor divesting effective control or beneficial ownership of the trust property. This is a common kind of legal claim: you failed to create the legal arrangement that you intended. It is often termed "recharacterisation" because it identifies the "true effect" of the documents that created a transaction, rather than relying on the name given to the arrangement by its creators. ${ }^{5}$

From another form/substance perspective, the Pugachev decision also highlights the main underlying substantive reasons that motivate illusory trust claims, namely the development of modern discretionary trusts that include settlor control through reserved powers. These powers make suspect the assertion that the settlor has disposed of the trust property so that it cannot be used to satisfy claims against him. ${ }^{6}$ One might say that one should "look through" the "form" of the trust as a property structure that divests the settlor of ownership to see the "substance" of the settlor's control. Indeed, Pugachev and ITD arguments more generally have been criticised for being based on such substantive (or "instrumental") reasoning, rather than being grounded in sound legal principles. ${ }^{7}$

This debate links with the main form/substance distinction in PS Atiyah and RS Summers' classic discussion - Form and Substance in Anglo-American Law - which focusses attention on whether this substantive reason for settlor control is connected to any formal legal doctrine within the law of trusts that can lead to an arrangement being invalid as a trust. ${ }^{8}$ If it can be, then it is wrong to say, as Birss $\mathrm{J}$ did in Pugachev, that the ITD looks beyond the form of the trust to its substance, apart from the sense in which the words contained in the trust deed use the nomenclature of trusts. ${ }^{9}$ It is better to say, as Birss J did elsewhere, ${ }^{10}$ that the ITD simply applies the formal law of trust, interpreting an unusual arrangement in its context, and finding (or not so finding) that the arrangement lacks the necessary features of a trust.

This article thus claims that although the ITD has been criticised as doctrinally unfounded and therefore based in substantive, non-legal reasons rather than pre-existing law, there are formal reasons of trusts law to support it. It begins by considering Atiyah and Summers' concepts of form and

5 See for example Pey-Woan Lee "Form, Substance and Recharacterisation" in Andrew Robertson and James Goudkamp (eds) Form and Substance in the Law of Obligations (Hart Publishing, Oxford, 2019) 71.

6 Pugachev, above n 3, at [176]-[182].

7 See below Part V: "Criticism of the ITD decisions".

8 PS Atiyah and RS Summers Form and Substance in Anglo-American Law: A Comparative Study in Legal Reasoning, Legal Theory, and Legal Institutions (Clarendon Press, Oxford, 1987).

9 Pugachev, above n 3, at [167], [245] and [278].

10 At [212] and [455]. 
substance, and then examines how they apply in the context of equity (in general), and then trusts law (in particular). It then briefly considers a number of recent decisions on the ITD: the four cases constituting the Clayton v Clayton litigation in New Zealand, ${ }^{11}$ Pugachev and the Cook Islands Court of Appeal and Privy Council decisions in Webb $v$ Webb. ${ }^{12}$ Finally, it analyses these ITD decisions using the form and substance distinction, concluding that it is arguable that the ITD is grounded in principles of established trust law, as opposed to purely substantive reasoning.

\section{FORM AND SUBSTANCE IN THE LAW}

\section{$A$ Atiyah and Summers on Form and Substance in Legal Reasoning}

One of the key concepts of form and substance in the law is that legal reasoning is formal where it applies pre-existing legal rules and principles to facts, and contrastingly substantive when it turns away from the pre-existing law and decides cases on the basis of substantive reasons of morality or efficiency. Accordingly, Atiyah and Summers introduce the concepts of form and substance in legal reasoning by stating that a formal reason in the legal realm is "a legally authoritative reason on which judges and others are empowered or required to base a decision or action". ${ }^{13}$ In contrast, a substantive reason is a "moral, economic, political, institutional, or other social consideration" that exists independent of the law. ${ }^{14}$

Formal legal reasoning must be analysed further, as it has a number of aspects. The most important kind of formality identified by Atiyah and Summers is "validity" formality, which refers to the fact that reasons become formal legal reason due to being legally authoritative, which is "mainly a function of satisfying a standard of validity". ${ }^{15}$ That is what makes those reasons part of the pre-existing law. Ideally, substantive reasons will be made valid legal rules, giving them the dual nature of being both substantive and, through their incorporation into the law, formal elements. Thus "a purely substantive reason cannot ... exist in the law"16 because if a substantive reason is part of the law it must have the

11 MAC v MAC FC Rotorua FAM-2007-63-652, 2 December 2011; Clayton v Clayton [2013] NZHC 309, [2013] 3 NZLR 236 [Clayton v Clayton (HC)]; Clayton v Clayton [2015] NZCA 30, [2015] 3 NZLR 293 [Clayton v Clayton (CA)]; and Clayton v Clayton [2016] NZSC 29, [2016] 1 NZLR 551 [Clayton v Clayton (SC)].

$12 W e b b v$ Webb [2017] CKCA 4 [Webb v Webb (CA)]; and Webb v Webb [2020] UKPC 22 [Webb $v$ Webb $(\mathrm{PC})]$.

13 Atiyah and Summers, above n 8, at 2.

14 At 1 .

15 Robert S Summers "Form and Substance in Anglo-American Law" (1987) 14 Cornell L Forum 2 at 2. See also Robert S Summers "Two Types of Substantive Reasons: The Core of a Theory of Common Law Justification" (1978) 63 Cornell L Rev 707 at 710.

16 Atiyah and Summers, above n 8, at 19. 
attribute of validity formality to some degree. ${ }^{17}$ But in non-ideal legal systems, some substantive reason will not exist in the law at all.

Another key aspect of law's formality is that a formal legal reason also has the attribute of "mandatory formality" in that it "usually excludes from consideration, overrides, or at least diminishes the weight of, any countervailing substantive reason arising at the point of decision or action". ${ }^{18}$ This feature of legal formality forms part of the philosophical discussion as to how legal systems should balance pre-existing legal rules when they clash with underlying substantive reasons. ${ }^{19}$ But unless there is some mandatory formality, there can be no practical distinction between reasons that are currently valid and those substantive reasons that are not legally valid but bear on the decision to be made. ${ }^{20}$

\section{$B$ "Substance over Form" in the Law}

In addition to Atiyah and Summers' categories in Form and Substance, there is also an idea found in some legal fields that courts should give effect to the "substance" of an arrangement or transaction where a person has achieved a substantive result by using a "form" of artificial legal structure. ${ }^{21}$ Where they do so, the courts' reason for putting substance over form is to uphold the substantive reasons found in the statute that places obligations on people who engage in certain arrangements or transactions. Artificial arrangements that subvert the evident purpose of a statute may be thought of as "shams" (the United States approach) ${ }^{22}$ or "avoidance" (the approach of many common law jurisdictions). ${ }^{23}$ This is often explicitly justified as a purposive interpretation of the statute. ${ }^{24}$ For

17 At 19.

18 At 2 .

19 See for example Larry Alexander and Emily Sherwin The Rule of Rules: Morality, Rules, and the Dilemma of Law (Duke University Press, North Carolina, 2001); Frederick Schauer Playing by the Rules: A Philosophical Examination of Rule-Based Decision-Making in Law and in Life (Oxford University Press, Oxford, 1993); and Ronald Dworkin Law's Empire (Belknap Press, Cambridge (Mass), 1986).

20 See Schauer, above n 19, at ch 8.6: "Presumptive Positivism".

21 See generally Edwin Simpson and Miranda Stewart Sham Transactions (Oxford University Press, Oxford, 2013).

22 See Joshua D Blank and Nancy Staudt "Sham Transactions in the United States" in Edwin Simpson and Miranda Stewart (eds) Sham Transactions (Oxford University Press, Oxford, 2013) 68; Phillip F Postlewaite "The Status of the Judicial Sham Doctrine in the United States" (2005) 15 Revenue LJ 140; and Robert S Summers "A Critique of the Business-Purpose Doctrine" (1961) 41 Or L Rev 38.

23 John Vella "Sham, Tax Avoidance, and 'A Realistic View of Facts' in the UK" in Edwin Simpson and Miranda Stewart (eds) Sham Transactions (Oxford University Press, Oxford, 2013) 259.

24 See Edwin Simpson "Sham and Purposive Statutory Construction" in Edwin Simpson and Miranda Stewart (eds) Sham Transactions (Oxford University Press, Oxford, 2013) 86. 
example, in tax law, courts may hold that tax should be levied with reference to the "economic substance" or a "realistic" understanding of an arrangement or transaction rather than with reference to its formal legal nature. ${ }^{25}$ Similarly, in the area of relationship property, courts in England, Australia and New Zealand have been able to look "behind legal trust structures to consider the reality of actual control", ${ }^{26}$ again citing statutory purpose to confer legitimacy on the substance over form approach. ${ }^{27}$

How does this concept of form and substance relate to Atiyah and Summers' concepts? These senses of form and substance contrast the strict legal position of the arrangements or transactions according to the "internal" law of the transaction (property, trusts, contract) with their actual substantive or "functional" 28 effect relative to some external objective. ${ }^{29}$ If a legal system applies, rather than rejects, such reasoning, it is clearly giving effect to the substantive reasons of that external objective, along with the substantive reason of countering avoidance of the regime. According to Atiyah and Summers' categories, this kind of substance over form route for anti-avoidance has low "content formality", being a general standard ("does this arrangement/result subvert the purpose of the statute?") rather than being specified in hard and fast rules. ${ }^{30}$ It may be created through purposive interpretations of the external statutory regime, or by express legislative authorisations such as a general anti-avoidance rule in tax - the latter having higher validity formality than the former. Another means of anti-avoidance are targeted rules for particular methods of avoidance. These have much greater content formality, and again, usually have high validity formality because they are created by statute.

To distinguish this sense of form and substance from Atiyah and Summers' uses of the terms in legal reasoning, I will call this the "substance over form" sense.

25 Gregory v Helvering 293 US 465 (1935); Barclays Mercantile Business Finance Ltd v Mawson [2004] UKHL 51, [2005] 1 AC 684; Ben Nevis Forestry Ventures Ltd v Commissioner of Inland Revenue [2008] NZSC 115, [2009] 2 NZLR 289; E W Thomas "The Evolution from Form to Substance in Tax Law: The Demise of the Dysfunctional 'Metwand" (2011) 19(2) Waikato L Rev 17; and Vella, above n 23.

26 Diana Bryant "Heterodox is the new orthodox-discretionary trusts and family law: a general law comparison" (2014) 20 T \& T 654 at 661.

27 Kennon v Spry [2008] HCA 56, (2008) 238 CLR 366; and Bryant, above n 26, at 654.

28 See Jesse Wall "The functional-formal impasse in (trust) property" (2017) 14 Int JLC 437.

29 This characterisation of legal areas as "external" and comparison with "internal" trusts law is elaborated in Tobias J Barkley "Discretionary Interests and Rights to Replace Trustees: Can They Be Property?" (LLM Thesis, University of Otago, 2012) at 1-14; and Mark Bennett "Competing Views on Illusory Trusts: The Clayton v Clayton litigation in its wider context" (2017) $11 \mathrm{~J} \mathrm{Eq} 48$ at 57-58.

30 Atiyah and Summers, above n 8, at 13-17. 


\section{Formality, Substance and Equity}

These "substance over form" concepts can be understood as linked with the legal and philosophical concepts of equity. Atiyah and Summers say that there is always a limit to the formality of the law: 31

At some point, formal reasons may produce results which are so obnoxious to all substantive considerations that the decision-maker will reject the mandatory formality of the formal reason and treat the substantive reasons underlying the formal rule as outweighed by newly emerging substantive considerations.

Yet Atiyah and Summers do not discuss equity in any detail - either in its philosophical or legal guise. A legal-philosophical approach has been championed by Henry Smith, who argues that equity is a necessary "second-order safety valve" on the law, aimed at "deterring opportunism". ${ }^{32}$ The idea of opportunism is that "law's generality results in exploitable gaps between the law and its purpose. These gaps give an opening to opportunists, which equity seeks to close". ${ }^{33} \mathrm{~A}$ monograph on form and substance in legal reasoning seems exactly the place to discuss equity, but it hardly receives a mention from Atiyah and Summers.

This might be because they agreed with the longstanding view that Equity has become a rigid body of rules rather than an exceptional jurisdiction. ${ }^{34}$ For example, Sir John Salmond said in 1902 that Equity was "no longer opposed to jus, but is itself a particular kind of jus", 35 "a scheme of rigid, technical, predetermined principles". ${ }^{36}$ Frederick Schauer similarly observed that "[t]he openendedness of equitable jurisdiction has been replaced by a rule-based system of equity that bears few methodological affinities with its Aristotelian roots." ${ }^{37}$ In this vein, Atiyah's inaugural lecture

31 At 20.

32 Henry E Smith Equity as Second-Order Law: The Problem of Opportunism (Harvard Public Law Working Paper No 15-13) at 4. See also generally Dennis Klimchuk, Irit Samet and Henry E Smith Philosophical Foundations of the Law of Equity (Oxford University Press, Oxford, 2020).

33 Henry E Smith "Why Fiduciary Law is Equitable" in Andrew S Gold and Paul B Miller (eds) Philosophical Foundations of Fiduciary Law (Oxford University Press, Oxford, 2014) 261 at 264.

34 Sarah Worthington Equity (2nd ed, Oxford University Press, Oxford, 2006); Sarah Worthington "Integrating Equity and the Common Law" (2002) 55 CLP 223; and Roscoe Pound "The Decadence of Equity" (1905) 5 Colum L Rev 20 at 24: "Although we may believe, on whatever grounds, in a resurrection of equity in the remote future, the present is a period of law." See also Douglas Laycock "The Triumph of Equity" (1993) 56 Law \& Contemp Probs 53.

35 John W Salmond Jurisprudence or the Theory of Law (Stevens \& Haynes, London, 1902) at 50. Salmond translates "jus" to "law" in later editions.

36 At 51 .

37 Frederick Schauer "The Failure of the Common Law" (2004) 36 Ariz St LJ 765 at 773 (footnotes omitted). 
portrayed the Judicature Act as signalling the end of Equity as a "residuary system of discretionary justice invoked in particular cases to temper the harshness of the law but not replacing the ordinary law in the generality of cases". ${ }^{38}$ For his part, Summers thought that instrumentalism was dominant in American law, ${ }^{39}$ which perhaps crowded out equity in his thinking.

Atiyah and Summers, in one of their few mentions of equity in Form and Substance, do seem to agree with the basic picture of equity as a "form over substance" backstop within formal systems of law. ${ }^{40}$ But it is a shame that equity is not examined further, because it would have allowed them to analyse their concepts in relation to the "substance over form" concepts that exist in the law, which seem an important aspect of their topic.

Indeed, the interplay of formal rules and substantive reasons, and the role of Equity, finds perhaps its greatest importance in the analysis of the trust. For the trust has always been, at least in part, a device allowing people to avoid liabilities of owning property, often while retaining effective control over it. ${ }^{41}$ One might say that the trust itself provides avenues for opportunism, so that equity turns in on itself. The courts should therefore support the ITD as a means of preventing form from subverting substance, as a matter of internal trusts law. This would, perhaps, be a break from the permissive approach that has operated for many years. The standard history of the trust may be interpreted as supporting this dynamic of form and substance, in the substance over form sense, and it is set out below in a potted form. But despite all of this, this article rejects the view that the ITD is straightforwardly "substance over form" reasoning.

\section{FORM AND SUBSTANCE IN TRUSTS}

\section{A A Story of the Trust as Form over Substance}

Trusts began as "uses" of land, ${ }^{42}$ where land was held by feoffee que use for the benefit of another, such that the common law owner of the land is therefore not supposed to be the owner in substance. The use allowed its creator to conduct fraud, avoid feudal dues, or to make a will of land or create

38 PS Atiyah "From Principles to Pragmatism: Changes in the Function of the Judicial Process and the Law" (1980) 65 Iowa L Rev 1249 at 1252.

39 Robert S Summers "Pragmatic Instrumentalism in Twentieth Century American Legal Thought: A Synthesis and Critique of Our Dominant General Theory About Law and its Use" (1981) 66 Cornell L Rev 861.

40 Atiyah and Summers, above n 8, at 91.

41 Austin W Scott "The Trust as an Instrument of Law Reform" (1922) 31 Yale LJ 457; Maitland, above n 1, at 25-30; Bennett, above n 29; and Mark Bennett and Adam S Hofri-Winogradow "Against Subversion: a Contribution to the Normative Theory of Trust Law" (2020) OJLS (forthcoming).

42 For current purposes, I rely mainly on AWB Simpson A History of the Land Law (2nd ed, Oxford University Press, Oxford, 1986). 
settlements. ${ }^{43}$ It was not part of the common law of real property, which protected seisin or possession - and the beneficiary did not have seisin. ${ }^{44}$ The strict formalism of the writ guaranteed the "helplessness of the common-lawyers in the matter". ${ }^{45}$ It has been observed that before the Chancery courts began giving a remedy to disappointed beneficiaries in the middle of the 15th century, the use must have been "a purely informal device, dependent for its efficacy on moral suasion and familial influence, and therefore of uncertain reliability". 46

But once it became usual for the Chancellors to grant relief to claimants, they developed general principles that they would apply in all relevant cases, so that the use became "a species of protected interest which will be defended consistently and predictably - that is, a species of property". ${ }^{47}$ Equity thereby enabled the creation of a parallel system of formal property rules, one that could be used to provide property owners with various advantages. The practical result, as Maitland says, was that "the Trust became very busy". 48

The eventual ubiquity of this new legal institution upset the liabilities of real property ownership under feudalism. ${ }^{49}$ Some, certainly the King, saw it as an evasion, contrary to the substance of ownership of the cestui que use: it was the latter "who beneficially enjoyed the land", and the trust allowed that person to "die, inherit, commit felony, and leave his interest by will even if he had no heirs; he never had to pay the incidents of tenure". ${ }^{50}$ To return to Maitland: "[t]he whole nation seems to enter into one large conspiracy to evade its own laws, to evade laws which it has not the courage to reform." 51

43 At $174-175$.

44 At 175 .

45 At 175

46 Richard Helmholz "Trusts in the English Ecclesiastical Courts 1300-1640" in Richard Helmholz and Reinhard Zimmermann (eds) Itinera Fiduciae: Trust and Treuhand in Historical Perspective (Duncker \& Humblot, Berlin, 1998) 153 at 157. Helmholz challenges this view due to historical evidence that uses were sometimes enforced in the ecclesiastical courts from the 1300s under their jurisdiction over testaments and oaths.

47 Simpson, above $\mathrm{n} 42$, at 177.

48 FW Maitland "Trust and Corporation" in HAL Fisher (ed) The Collected Papers of Frederick William Maitland (Cambridge University Press, Cambridge, 1911) vol 3 at 353

49 Simpson, above $\mathrm{n} 42$, at 183.

50 At 183

51 FW Maitland "Outlines of English Legal History, 560-1600" in HAL Fisher (ed) The Collected Papers of Frederick William Maitland (Cambridge University Press, Cambridge, 1911) vol 3 at 492. 
The response to these evasions was to pass statutes to counter them, initially simply looking through the feoffee's seisin to identify the substance of ownership in the cestui que use, treating the latter "as if he had the legal estate"52 and imposing on them the liability of ownership. ${ }^{53}$ The more radical approach was taken with the Statute of Uses 1535, which destroyed uses by vesting the legal estate in the cestui que use. ${ }^{54}$ Instead of attaching liabilities to the substantive owner, it destroyed the distinction between the formal and substantive owner: ${ }^{55}$

... it was drafted with the intention of clearing the feoffees to uses out of the picture in all cases, and thus abolishing generally the separation of the legal estate from the equitable estate. By doing this ... the evasion of feudal incidents (in which he certainly was) would be prevented, for those ... evasions all depended upon this separation of legal title from beneficial enjoyment.

This was a failure, due to exceptions to the statute and the efforts of clever lawyers in saving the idea of the division of beneficial and legal title to property through the trust.

\section{B Modern Trusts Practice}

However, I skip over the history of the development of the trust proper, because the purpose of the above discussion is merely to gesture towards the interplay of the exploitation of formal property rules and substantive reasons relating to the liabilities of ownership. The exploitation mechanisms were soon subject to anti-avoidance measures that looked to the real substance of beneficial ownership. That same general pattern may be discerned in the development of the modern trust. As soon as the trust was institutionalised as something the Equity courts would invariably enforce, there was a "formal" set of rules defining its structure and effect. This was deployed to avoid liabilities of property ownership, with an eye on the high tax rates that funded war and welfare in the early 20th century. 56

Yet the basic trick of separating legal and beneficial title has been understood and often nullified by the legislature. In the second half of the 20th century new trust structures arose that meant that no one had any fixed beneficial right, even if they retained control over the trust. "[T]he forms and functions of settlements have changed to a degree which would have astonished Lord Eldon". ${ }^{57}$ In

52 Simpson, above n 42, at 185; and Maitland, above n 1, at 34.

53 Simpson, above n 42, at 184

54 Simpson, above n 42, at 184-185; and Maitland, above n 1, at 35. See Statute of Uses 1535 (Eng) 27 Hen VIII c 10 .

55 Simpson, above n 42, at 186.

56 See Jonathan Garton Moffat's Trusts Law: Texts and Materials (6th ed, Cambridge University Press, Cambridge, 2015) at ch 3; and GSA Wheatcroft "The Attitude of the Legislature and the Courts to Tax Avoidance" (1955) 18(3) MLR 14

57 Schmidt v Rosewood Trust Ltd [2003] UKPC 26, [2003] 2 AC 709 at [34]. 
Pugachev, Birss J casts a sceptical eye on such arrangements, noting that "unscrupulous persons" who wish to keep their property out of the hands of their creditors may through such a discretionary trust "hide their relationship with the property" and "truly state that they have no proprietary interest in or beneficial ownership of the property". 58

For example, settlors often create "massively discretionary" trusts, with a charity or a family member as the only named beneficiary (as final beneficiary), and other powers of appointment or trust powers being exercisable in favour of persons to be added by the trustees at a later date. ${ }^{59}$ Although this may divest the settlor of ownership for the purposes of certain ownership liabilities, Birss J notes a problem for the unscrupulous person: ${ }^{60}$

$\ldots$ if a person gives away their property to someone else then it is no longer theirs. But that is not what the unscrupulous person in the example wants to do at all. As far as they are concerned the property is theirs. The objective is not to lose control of it, the objective is to hide it and protect it from creditors. ... The problem for the unscrupulous person is that in the kind of discretionary trust discussed so far, all the power is in the hands of the trustees.

But there is a solution. The settlor can retain powers to control the trustees such as the power to add and replace trustees and to veto trustee decisions. ${ }^{61}$ The substance of effective control of the trust is ensured by the form of the trust, but the orthodox legal rules mean that they are not the owner of the property - and not subject to the liabilities of ownership. Birss J's narrative is reminiscent of Diplock J's observations of how the "lawyer turns magician" by creating legal structures that make the substance of an arrangement vanish. ${ }^{62}$

The question is whether the law should respond to this concern about the form of the transaction hiding its substance. This leads to the questions that determined the case in Pugachev: if the protector holds the powers for his own benefit rather than as a fiduciary for the discretionary beneficiaries, is the arrangement a trust for the beneficiaries? As observed in Tasarruf Mevduati Sigorta Fonu $v$ Merrill Lynch Bank, the law often looks through the strict property rules to make the "effective" or

58 Pugachev, above n 3, at [178] and [174].

59 Schmidt v Rosewood, above n 57, at [34]-[35]; Pugachev, above n 3, at [173]; and Lionel Smith "Massively Discretionary Trusts" (2017) 70 CLP 17.

60 Pugachev, above n 3, at [179]-[180].

61 At [180].

62 Morgan v IRC [1963] Ch 438 (CA) at 455, as quoted in Tasarruf Mevduati Sigorta Fonu v Merrill Lynch Bank [2011] UKPC 17, [2012] 1 WLR 1721 [TMSF] at [39]. 
"in substance" owner liable. ${ }^{63}$ The issue then arises: how should we understand situations in which trusts are set up but the settlor retains effective control over the trust property?

In another kind of case, a family trust is established with the children and/or grandchildren as final beneficiaries, but with the settlor as one of the discretionary beneficiaries (ie, the object of a trust power or power of appointment), and often as one of the trustees or the sole trustee, with powers to add or remove beneficiaries and to appoint or remove trustees. An example is the New Zealand case Kain v Hutton, in which property held on trust was appointed to a legitimate object of the power to appoint capital and then immediately resettled on a new trust. ${ }^{64}$ Only one of the beneficiaries of the new trust (Mrs Couper) was an object of the appointment of capital under the old trust. Therefore, it was argued that the appointment and new trust were part of a scheme to confer benefits on non-objects - a fraud on the power.

Analysing this argument, the New Zealand Supreme Court found that even though the transactions might appear to be a fraud on the power, they were to the benefit of a valid object. The new trust had discretionary beneficiaries who were not objects of the old trust's power to appoint capital, but was "not only established and controlled by Mrs Couper but one which was very much for her own benefit." 65 The Supreme Court observed that: ${ }^{66}$

... the trustees with [Mrs Couper's] participation gave her not only personal benefit - she could ensure, if she wished it, that the shares would revert to her - but also the benefit of being able to assist her daughters if she thought that course appropriate in the future. ... Nothing could be done without her concurrence as a trustee. ... It put her in effective control of those shares with the ability to take the benefit herself or, if she saw fit, to pass all or some of it to her daughters or other family members. The factor which makes it impossible to accept that the resettlement was somehow forced on her for the benefit of non-objects is her complete ongoing control of the trust through the ability to appoint and remove trustees and discretionary beneficiaries.

This is a striking argument, given the existence of other independent trustees who were charged with the usual fiduciary obligations and the power to make distributions of trust property. The formal legal position was that Mrs Couper stood alongside the trustees in that position, with the same duties and powers. Any decision about distributing trust property could only be made by all trustees together, in light of their fiduciary obligations. But because Mrs Couper could appoint and remove trustees and discretionary beneficiaries, and was one of the beneficiaries of the trust, the Supreme Court stated that

$63 T M S F$, above $\mathrm{n}$ 62, at [40]-[50] and for application of these concepts: at [59], [60], and [62].

64 Kain v Hutton [2008] NZSC 61, [2008] 3 NZLR 589.

65 At [22].

66 At [22]-[23]. 
she could take the whole benefit of the trust property for herself. ${ }^{67}$ As the prominent New Zealand trusts lawyer Anthony Grant observed, the Supreme Court "sanctioned the validity of such Trusts even though the presence of 'effective control' of the Trust assets by a person is usually given as the very hallmark of invalidity". 68

\section{Form and Substance in "Looking Through" the Trust}

Modern trust practice creates a situation where, according to the rules of trusts law, property is ownerless for the purposes of many of the liabilities of ownership. ${ }^{69}$ Yet, as Kain v Hutton shows, settlors may retain effective control over the trust property. ${ }^{70}$ The question is therefore whether such settlor control that does not amount to legal ownership according to orthodox property law rules should be treated like ownership for any purpose. ${ }^{71}$ Where the law disregards the formal structure of the trust to say that the trust property can be attributed to the settlor for the purposes of the liabilities of ownership, we might say that we have "looked through" the trust. It gives effect to the "substance over form" approach to ownership.

The law looks through the trust in a number of ways in practice:

(1) External look through: where the trust deed provides excessive powers to a person, they might be treated by the external legal regimes (tax, relationship property, anti-money laundering, creditors' claims) as having effective control or being the beneficial owner. Here the arrangement is not ineffective in trusts law, but the external law looks through to the perceived substance of the arrangement.

(2) Sham: where the parties to a transaction never intended to actually give effect to the transaction as set out in the trust deed, there is a sham. This is a "look through" which is internal to the law of trusts.

(3) Illusory trust or recharacterisation: where the trust deed itself provides excessive powers to a person, that person might be treated by trusts law as the real owner of the property. This is the ITD and again internal to trusts law.

67 At [22]-[23]

68 Anthony Grant "The Supreme Court, Trusts, alter egos and shams" <http://anthonygrant.com>.

69 Andres Knobel Trusts: Weapons of Mass Injustice? (Tax Justice Network, 13 February 2017).

70 See Kain v Hutton, above n 64.

71 See the lucid analysis of this question in Wall, above n 28, at 14-17. See also Pablo A Hernández GonzálezBarreda Beneficial Ownership in Tax Law and Tax Treaties (Hart Publishing, Oxford, 2020) at ch 1. 
This article will consider the relationship between the ideas of form and substance, in both Atiyah and Summers' senses and the "substance over form" sense, to these various approaches to looking through the trust.

\section{External look through}

External statutory regimes that allow judges to look through trusts to attribute ownership to the person with effective control may be seen as subverting the formal rules of the law of trusts in favour of general discretions or standards that respond to the aims of the external regime. An example is some relationship property regimes where the statutory legal rules disregard the formal rules of property and trusts law to ensure that the substantive reasons underlying the relationship property regime are not frustrated. ${ }^{72}$ In England and Australia, the pool of property that is to be divided between spouses not only includes the property that they own according to the formal legal rules. ${ }^{73}$ The statutory definitions refer to "property" or "financial resources", and the courts have looked, with a "worldly realism" at the substance of the parties' control or ownership of the property to determine the pool of property to be redistributed between the spouses. ${ }^{74}$ In New Zealand, the Property (Relationships) Act 1976 refers only to "property" in determining the pool of relationship property, making it more difficult to simply point to substantive ownership or control where the formal property law rules mean that it is not the property of either relationship partner. ${ }^{75}$ Nevertheless, the Supreme Court in Clayton v Clayton was able to interpret "property" expansively, according to its statutory purpose, extending it to the extreme control held by Mr Clayton over trust property.

Therefore, the relationship property "look through" of trusts is a formal statutory rule that requires judges to deploy a standard with low content formality, accounting for the financial resources of the parties from a realistic perspective, and not simply their property as determined by the formal law. In this way, it can be said to put substance over legal form. But judges can usually justify their subversion of formal property rules by express direction in a statute, which has its own obvious validity formality. Alternatively, where there is no clear legislative direction to apply a wider content informal standard to determine the relationship property pool, judges refer to legislative purpose and to the desirability of achieving substantive justice to justify interpreting the statute to refer to a substantive concept of property rather than the formal legal concept.

72 Wall, above n 28, at 14-17.

73 Kennon v Spry, above n 27; and Matrimonial Causes Act 1973 (UK), s 25(2)(a).

74 Charman v Charman [2007] EWCA Civ 503, [2007] 1 FLR 1246 at [57]; and Clayton v Clayton (SC), above n 11, at [79].

75 For example ss 2,8 and 11. 


\section{Sham}

Within trusts law doctrine, there may also be an internal consequence of settlor control. If such control is not allowed under the trust deed but was intended by the trust parties from the start to be the true arrangement, the trust may be a sham. ${ }^{76} \mathrm{~A}$ sham is a legal arrangement or transaction that objectively contains certain rights and obligations on its face - in the formal documentation - that the parties subjectively do not intend to give effect to. ${ }^{77}$

It might be said that putting substance over form is evident in the sham doctrine. The Court of Appeal in Clayton $v$ Clayton stated that: ${ }^{78}$

To determine whether a particular transaction constitutes a sham, the court will focus on the actual intentions of the parties to the transaction and compare them with the acts done or documents created. In doing so, the court will not be restricted to the legal form of the transaction, but will examine its substance in light of all the relevant evidence relating to the parties' intentions. ... This approach reflects equity's preference for substance over form ...

Further, Conaglen notes that the sham doctrine is concerned with identifying the "real truth of the matter" or "real transaction"79 or "the substance of their agreement". ${ }^{80}$

This is not, however, the main use of Atiyah and Summers' relevant concepts of form and substance in legal reasoning considered in this article - that of authoritatively formal legal rules being disregarded to give effect to substantive reasons. In the case of the sham doctrine, there is an authoritatively formal legal rule that tells us to go beyond the written documentation of a legal arrangement or transaction where there is evidence that it was the subjective intention of the parties to never give effect to it. ${ }^{81}$ The sham doctrine relates to a different kind of form/substance distinction, between documents that constitute a legal form of a transaction and the transaction that the parties actually intend to give effect to. In doing so, it clearly gives effect to the "substantive" normative reason that the courts should not give effect to a pretence or façade, and that the legal position should

76 See Official Assignee v Wilson [2007] NZCA 122, [2008] 3 NZLR 45; Clayton v Clayton (SC), above n 11; and Pugachev, above n 3, at [166]-[169]

77 Miranda Stewart "The judicial doctrine in Australia" in Edwin Simpson and Miranda Stewart (eds) Sham Transactions (Oxford University Press, Oxford, 2013) 51; and Matthew Conaglen "Trusts and intention" in Edwin Simpson and Miranda Stewart (eds) Sham Transactions (Oxford University Press, Oxford, 2013) 122.

78 Clayton v Clayton (CA), above n 11, at [61]-[62] (footnotes omitted).

79 Conaglen "Trusts and Intention", above n 77, at [7.08].

80 Matthew Conaglen "Sham Trusts" (2008) 67 CLJ 176 at 183.

81 Snook $v$ London and West Riding Investments [1967] 2 QB 786 (CA); Hitch v Stone (Inspector of Taxes) [1999] STC 431 (Ch); Official Assignee v Wilson, above n 76; and Raftland Pty Ltd as trustee of the Raftland Trust v Commissioner of Taxation [2008] HCA 21, (2008) 238 CLR 516. 
be determined by reference to the truly intended arrangement or transaction. That true arrangement is determined according to orthodox legal categories, and is an exercise in reasoning that is formal rather than substantive, in the validity formality sense.

\section{Illusory trust (or recharacterisation)}

The idea of the ITD is that despite the use of the language associated with the creation of a trust, the legal arrangement created is not in fact a trust. As such, it can be understood as the trusts law instantiation of the more general legal phenomenon of "recharacterisation". 82 As Pey-Woan Lee has identified, recharacterisation takes the rights and obligations intended by the parties to a transaction, and asks what legal category they fit into. ${ }^{83}$ This latter analysis is a categorisation, which can only proceed once a court has identified "the 'objective criterion' that defines that particular category". ${ }^{84}$ Lee argues that categorisation is necessarily evaluative, looking to the values underlying the legal category. ${ }^{85}$ Turning to recharacterisation, Lee argues that it deals with courts' consideration of the legitimacy of individuals' attempts to "avoid particular legal classifications and their attendant legal consequences". ${ }^{86}$ Therefore the underlying moral, social and economic aims of the competing legal categories - the individual's preferred category and the one the transaction was structured to avoid become central to the court's evaluative task. ${ }^{87}$

As Lee presents it, the ITD is akin to external look through and sham doctrine in seeking to prevent "illegitimate avoidances". ${ }^{88}$ Courts recharacterising trusts therefore, Lee claims, should use substantive reasoning (using Atiyah and Summers' concept). ${ }^{89}$ She criticises courts for sometimes failing to recognise this, and instead applying formal rules and doctrine when recharacterising transactions. ${ }^{90}$ In particular, in discussing Birss J's decision in Pugachev, Lee argues that the formal reasoning that he deployed - with its emphasis on strong judicial authority - was meant to minimise the substantive concern in order to prevent the use of trusts to the detriment of creditors. ${ }^{91}$ From this perspective, the question Atiyah and Summers raise is whether the ITD too is based in formal legal

82 Lee, above n 5, at 71-73.

83 At 73.

84 At 73

85 At 73

86 At 74

87 At 74 .

88 At 74

89 At 75.

90 At 75

91 At 88 . 
reasoning within trusts law, or whether it is a new doctrine responding to substantive reasons. However, I will argue below that this is not the view of the recent decisions that have examined the ITD. Instead, the decisions have presented recharacterisation as depending on formal reasoning about the nature of trusts. Stated in Lee's language, courts are engaging in recharacterisation as a formal application of existing legal rules, namely the objective criteria that define the legal category of the express trust. As with sham, this reasoning is formal rather than substantive, in the validity formality sense.

That is a large "set up" for the discussion of the recent ITD decisions, but it is necessary in order to give a precise description of their arguments and to evaluate the commentary on them, within the categories of form and substance. I now turn to those cases.

\section{THE RECENT DEVELOPMENT OF THE ILLUSORY TRUST DOCTRINE (ITD)}

\section{A Clayton v Clayton}

The Clayton v Clayton litigation is a series of New Zealand cases concerning the ITD. I have analysed this case in detail elsewhere. ${ }^{92}$ Briefly, Mr Clayton and Mrs Clayton divorced and Mrs Clayton then claimed that the property Mr Clayton had settled on trust was in fact his own property. This was either because the trust was either a sham or not a trust at all due to the power he retained over the trust property. Mr Clayton was the sole trustee of this discretionary trust of which he was a beneficiary, as well as holding a number of powers usually reserved to protectors. There was also an express exclusion of the trustee's fiduciary obligations to the other beneficiaries.

Both the Family Court and High Court agreed that the trust was illusory due to Mr Clayton retaining beneficial ownership of the trust property. The High Court Judge Rodney Hansen J stated that Mr Clayton "effectively retained all the powers of ownership". 93 This went against the irreducible core of the trust as a disposition of ownership. The Court of Appeal overturned these decisions, saying that there was no ITD in trusts law, and that a trust is either a sham or valid. ${ }^{94}$ Nevertheless, it ruled for Mrs Clayton by taking the external look through approach, finding that the power Mr Clayton held over the trust property brought it into the property pool for the statutory relationship property regime. ${ }^{95}$

92 See Bennett, above n 29.

93 Clayton v Clayton (HC), above n 11, at [90].

94 Clayton v Clayton (CA), above n 11, at [77]-[79]

95 At [86]-[116]. 
The Supreme Court essentially agreed with the Court of Appeal on the result and the external means of reaching it. ${ }^{96}$ However, it disagreed with the Court of Appeal's rejection of the ITD. It stated that the ITD was possibly a feature of trusts law, but found that "[d]etermining which of these two lines of analysis is correct is a matter of some complexity on which the Court does not have a concluded unanimous view"97 and on which they did not have to, as they had allowed Mrs Clayton's claim on other grounds. ${ }^{98}$

\section{$B$ JSC Mezhdunarodniy Promyshlenniy Bank v Pugachev}

\section{The facts}

The Pugachev case is an English High Court decision from October 2017 which discussed the concepts of sham and illusory trusts in great detail. ${ }^{99}$ It concerned English assets held under New Zealand trusts, with the argument proceeding on the basis that New Zealand and English law were identical on the relevant matters of trusts doctrine. ${ }^{100} \mathrm{Mr}$ Pugachev was an extremely wealthy Russian who founded a large bank, Mezhprom Bank, and was heavily involved in politics, including the political rise of President Putin. ${ }^{101}$ Mr Pugachev fell out of favour with the Russian elite, the Bank became insolvent, and Mr Pugachev was accused of misappropriating huge sums of money from it. ${ }^{102}$ Orders were made against Mr Pugachev for large sums and he was subject to worldwide freezing orders. ${ }^{103}$ Mr Pugachev had to pay, but the question was: how much?

After the collapse of the bank and before the orders against him, Mr Pugachev had settled assets, including London property, on trusts. ${ }^{104}$ These were discretionary trusts, with Mr Pugachev and his family being among the named discretionary beneficiaries. ${ }^{105}$ The trustees were New Zealand companies, with the directors being certain of Mr Pugachev's lawyers and advisers. ${ }^{106}$ A significant

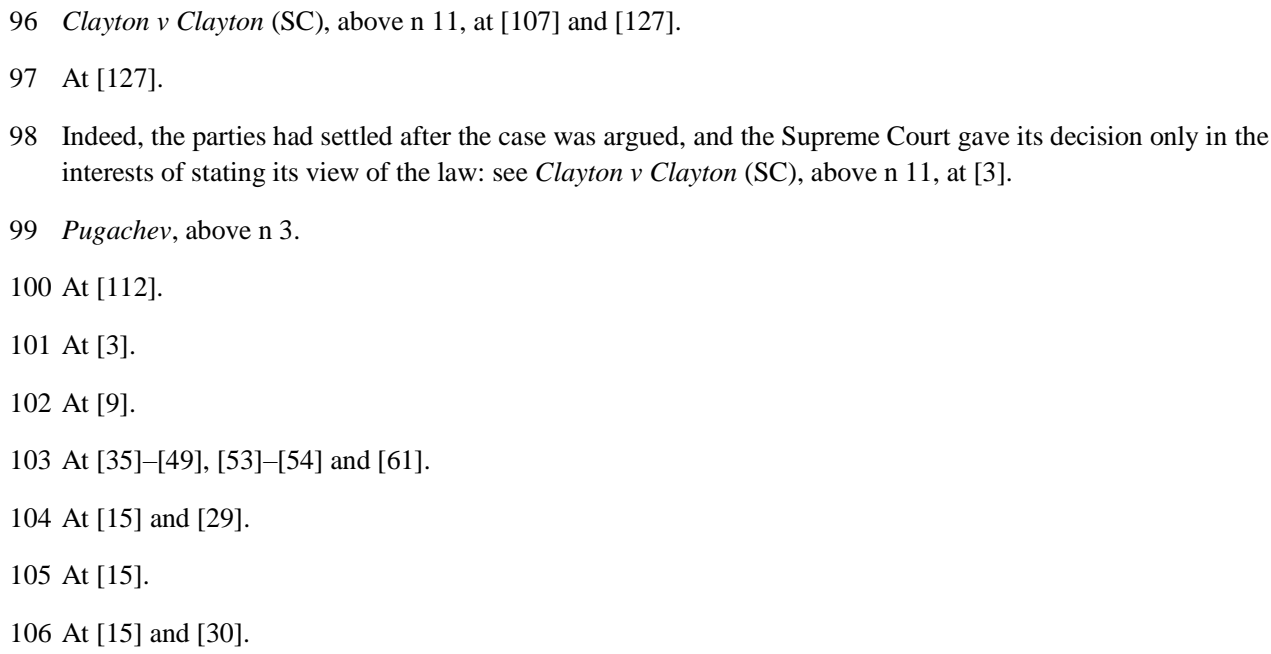


feature of these trusts was that Mr Pugachev held many powers as the trust's protector. It was asserted by the claimants that he held so much power over the trusts and their assets that the property was in fact his, rather than being held on the discretionary trusts for the beneficiaries. ${ }^{107}$

This claim was put in two ways. The first was the illusory trust claim: "that according to the terms of the deeds, properly construed and on a proper application of the law to them, the trusts were not effective to divest Mr Pugachev of his beneficial ownership of the assets put into them". ${ }^{108}$ Alternatively, if he did not hold such control, then the trusts were mere shams because it was always intended by the parties that Mr Pugachev would in fact exercise control amounting to beneficial ownership. ${ }^{109}$ In either case, the assets should be treated as beneficially owned by Mr Pugachev, thus forming part of his assets against which the court orders could be enforced.

Mr Pugachev and the other named beneficiaries contested these claims, arguing that these were valid trusts giving them enforceable rights and preventing the conclusion that Mr Pugachev had beneficial ownership in the trust property. ${ }^{110}$ The powers he held as protector were to be exercised in a fiduciary manner for the benefit of the beneficiaries. ${ }^{111}$ They were not shams because the trustees did not have the requisite intention to treat the property as owned by Mr Pugachev. ${ }^{112}$

\section{Mr Pugachev's powers}

Mr Pugachev had a vast array of powers under the trust deed. He was a discretionary beneficiary of the trusts with his wife, children and grandchildren. ${ }^{113}$ Through holding the office of protector, he could: add people to the pool of discretionary beneficiaries; ${ }^{114}$ add a new protector; ${ }^{115}$ and add trustees or remove them "with or without cause". ${ }^{116}$ The protector's prior written consent was also required before the trustee could exercise a number of trustee powers and discretions, namely the specification of a distribution date; the distribution of income or capital, investment of the trust fund, the removal of beneficiaries; variation of the trust deed; and the release or revocation of trustee

107 At [70].

108 At [71] and [225].

109 At [72].

110 At [76].

111 At [226].

112 At [76]-[77].

113 At [106].

114 At [106].

115 At [115].

116 At [127]. 
powers. ${ }^{117} \mathrm{Mr}$ Pugachev had a right to reside in the property, ${ }^{118}$ and he could also direct the sale of the residential property, subject to some restrictions. ${ }^{119}$ In addition, the trustee could (again, with the protector's prior written consent) distribute income and/or capital at any time, in any shares, to one or more of the discretionary beneficiaries. ${ }^{120}$

Although the trust deed gave Mr Pugachev significant power over the trust, the defendants argued that the illusory trust claim was not a possible cause of action under English law. ${ }^{121}$ They cited the Court of Appeal's argument in Clayton v Clayton that there was no ITD that could sit alongside the sham doctrine; ${ }^{122}$ indeed, the Court of Appeal in Clayton $v$ Clayton had rejected the ITD reasoning of the Family Court and High Court as legally ungrounded. ${ }^{123}$

In response to this, Birss J noted that the Supreme Court in Clayton v Clayton had set aside the Court of Appeal's finding concerning the ITD, and had accepted that it may be possible to argue that a trustee "retains such control that the proper construction is that he did not intend to give or part with control over the property sufficient to create a trust". ${ }^{124} \mathrm{He}$ observed that the Supreme Court's decision "illuminates some important principles" relevant to the illusory trust claim: ${ }^{125}$

The case shows that when considering what powers a person actually has as a result of a trust deed, the court is entitled to construe the powers and duties as a whole and work out what is going on, as a matter of substance. Even though the VRPT deed in that case named more than one Discretionary Beneficiary and named Final Beneficiaries which did not include Mr Clayton, when the deed is examined with care, what emerged is that in fact Mr Clayton had effectively retained the powers of ownership.

Thus, the test for illusory trusts Birss $\mathrm{J}$ discerns from Clayton $v$ Clayton is whether the rights and duties in the deed mean that in substance the settlor retains the powers of ownership.

\section{Discretionary trusts, protectors and fiduciaries}

Birss $\mathbf{J}$ proceeded to further elaborate on this basic concept of illusory trusts with a general discussion of trusts law. His discussion began with reference to the Bermuda case Re AQ Revocable

117 At [116].

118 At [118].

119 At [115].

120 At [119]-[120].

121 At [156].

122 At [157]-[158].

123 At [158]. See also Clayton v Clayton (CA), above n 11, at [53]-[79].

124 Clayton v Clayton (SC) at [119], as cited in Pugachev, above n 3, at [162].

125 At [167]. 
Trust, ${ }^{126}$ a then recent Commonwealth case that had found a trust to be illusory. However that decision does not play any other role in his decision; Clayton v Clayton was the dominant authority. Birss J's analysis instead proceeded by noting the concept of the irreducible core of trusts, ${ }^{127}$ clearly aiming to further establish an orthodox doctrinal basis for the ITD.

However the next section of the decision goes beyond doctrine, and provides a realistic understanding of Mr Pugachev's powers in the context of modern discretionary trusts. Birss J noted the way that discretionary trusts separate legal from beneficial ownership, allowing people to protect assets from the liabilities of ownership. ${ }^{128}$ Although the law recognises beneficial ownership, discretionary trusts create another avenue of making the property ownerless. ${ }^{129}$ All of this is couched in relation to "unscrupulous persons" who wish to rid themselves of the liabilities of property ownership. But this unscrupulousness does not end there, because such a person will not want to lose control over the property, which will occur if they settle the property on a discretionary trust of which they are not trustee over. ${ }^{130}$ Therefore, they retain powers, in this case as the protector. ${ }^{131}$ Often, a court will find that the protector is really meant to be ensuring the trustees do their job properly, and must exercise their powers under fiduciary constraints. ${ }^{132}$

Yet where the intention is that of an unscrupulous person and is to retain control while protecting their assets from creditors, we might interpret their powers as being held in a non-fiduciary capacity. The result, Birss J observes, is that: ${ }^{133}$

... the unscrupulous person can prevent the trustees from distributing the money to anyone but himself (or herself) and can remove recalcitrant trustees who fail to do his or her bidding and replace them with trustees willing to do what the unscrupulous person wants. Viewed in that way, perhaps the discretionary trust is not really a discretionary trust at all; the unscrupulous person has retained effective control of the assets or at least can recover that control whenever they like.

126 Re AQ Revocable Trusts [2010] SC (Bda) 40 Civ.

127 Pugachev, above n 3, at [170]-[172].

128 At [173]-[175].

129 At [176]-[178]

130 At [179].

131 At [180]

132 At [181].

133 At [182]. 
This payoff identifies the principle of trusts law that Birss $\mathrm{J}$ applied, but the entire lead up seems more of a justification of the substantive reasons for preventing people from "having their cake and eating it" by disposing of property but retaining effective control over it.

Birss $\mathbf{J}$ then turned to the discussion of the law in textbooks. He noted that Underhill \& Hayton Law of Trusts and Trustees was cited by the claimants for the proposition that the retention of settler power may support a claim that the trust is a bare trust for the settlor. ${ }^{134}$ Yet, the bulk of the analysis in Pugachev concerns the question of whether a protector's powers must be fiduciary or can be nonfiduciary. ${ }^{135}$ Birss J concludes that: ${ }^{136}$

What matters is whether or not a power given to a protector is purely personal, in the sense that it can be exercised in the protector's own selfish interests. A power will not be purely personal if it must be exercised for a purpose, such as having regard to the interests of the Discretionary Beneficiaries as a whole or in order to promote the objects of the trust. In that case the exercise of the power will be subject to the court's supervision.

This is determined by interpreting the deed, "taking into account all relevant circumstances (which do not include the subjective intentions of the settlor)". ${ }^{137}$ These relevant circumstances include the role of the protector as settlor, trustee, and/or discretionary beneficiary and the powers that have been conferred on the protector.

\section{Conclusions on Mr Pugachev's trusts}

Taken as a whole, Birss $\mathbf{J}$ found that Mr Pugachev's trust deeds' true effect was to make $\mathrm{Mr}$ Pugachev the beneficial owner. In the terms I favour, the express trust was illusory. While the first impression of the trust deeds suggested that Mr Pugachev's powers as protector were meant to be exercised to benefit the discretionary beneficiaries, Birss $J$ was driven to interpret them as "conferred to be exercised freely for his own benefit". ${ }^{138}$ The "fundamental reason" was the "extensive nature" of the powers combined with Mr Pugachev being the settlor and a named discretionary beneficiary. ${ }^{139}$ Birss J explained further that: ${ }^{140}$

134 At [189]. See David Hayton, Paul Matthews and Charles Mitchell Underhill \& Hayton Law of Trusts and Trustees (19th ed, LexisNexis Butterworths, London, 2018).

135 At [190]-[202].

136 At [203].

137 At [203].

138 At [267].

139 At [268].

140 At [268]. 
If such extensive powers had been conferred on a third party as protector, with provisions barring that person from being a beneficiary, then I can see that a different result might follow but the fact it is a beneficiary on whom these powers are conferred militates against the idea of a limitation. One would expect a beneficiary ordinarily to be entitled to act in their own interests. Conversely if less extensive powers were conferred on a beneficiary/protector then again one might arrive at a different result but that is not this case.

Once Mr Pugachev's powers were found to be non-fiduciary, it was a short step for Birss J to conclude that: ${ }^{141}$

... on their own terms these trusts do not divest Mr Pugachev of the beneficial ownership he had of the assets transferred into them. In substance the deeds allow Mr Pugachev to retain his beneficial ownership of the assets.

It is remarkable that a case that applied the ITD spent most of its analysis on a contextual description of the unscrupulous uses of discretionary trusts, the question of when a protector's powers will be interpreted as fiduciary, and the application of the law to the "factual matrix". ${ }^{142}$ The implication is that the ITD is an orthodox approach to trusts, complicated only by the interpretation of the trust deed in its context.

\section{$C$ Webb v Webb}

The Webb $v$ Webb cases are from the Cook Islands courts. The Court of Appeal decision from late 2017 applied the ITD, and this was upheld by the Privy Council's decision in 2020. The cases concerned a dispute that had essentially the same structure as Clayton. A New Zealand couple were married for a number of years, the later of which they spent in the Cook Islands where they held most of their assets. ${ }^{143}$ They separated, and Mrs Webb issued matrimonial property proceedings in the Cook Islands High Court, on the basis of the relationship property regime found in the Matrimonial Property Act $1976 .{ }^{144} \mathrm{Mr}$ Webb claimed that he held no property that could be matrimonial property, ${ }^{145}$ in part because he had settled much of his property into trusts in the Cook Islands. ${ }^{146}$ However, Mrs Webb argued that these trusts were invalid and that the trust property was matrimonial

141 At [278].

142 At [212].

$143 W e b b v$ Webb (CA), above n 12, at [1].

144 At [9]-[10]. New Zealand has since amended the Matrimonial Property Act 1976, which is now entitled the Property (Relationships) Act 1976.

145 At [12].

146 At [4]-[7]. 
property ${ }^{147}$ due to the limitations on beneficiary rights to accounts and information ${ }^{148}$ and Mr Webb's intention to retain ownership and control of the trust property. ${ }^{149}$ Neither argument succeeded in the High Court, with the Judge treating the latter argument as simply an assertion of a sham. Mrs Webb appealed on a number of grounds, including the validity of the trust deeds. ${ }^{150}$

The Court of Appeal agreed that the arrangements set out in the trust deeds did not amount to valid trusts, applying the ITD identified in Clayton $v$ Clayton and deployed in Pugachev. It began by stating, under the heading "Trust validity principles", that "[t]he key issue is whether, on an objective analysis of the powers reserved to the respondent in that deed, the settlor has evinced an intention to irrevocably relinquish a beneficial interest." 151 Counsel for Mrs Webb submitted that the deed was analogous to Mr Pugachev's. ${ }^{152}$ The Court noted the powers held by Mr Pugachev and observed that the English High Court had found that the existence of those powers meant that he "had not effectively alienated his beneficial ownership of the assets", so that there was no trust. ${ }^{153}$ The Court also seemed to accept an agreement between counsel that the ITD did exist within the law of trusts, and as such could have been used in Clayton $v$ Clayton to bring the trust property in the relationship property pool, even though the Supreme Court avoided that approach. ${ }^{154}$ The Court of Appeal therefore simply applied the illusory trust principle which required it to answer the "ultimate question" of "whether the powers reserved to [the settlor] were inconsistent with an intention to irrevocably relinquish a beneficial interest". ${ }^{155}$

The Court elaborated on this idea of relinquishing (or retaining) a beneficial interest as follows: ${ }^{156}$

The matter is best tested by asking what would have occurred if the respondent had attempted to recover the property which he ostensibly settled on the trust. If a critical step in such an attempt would have required the assent of a truly independent person, or would have been subject to an enforceable fiduciary duty on his part, it could not be said that the purported settlement on the trust was ineffective. Conversely if, on an objective view of the deed, the respondent had retained for himself the uncontrolled power to

147 At [11].

148 At [12].

149 At [13]

150 At [21].

151 At [53].

152 At [54]

153 At [54].

154 At [56].

155 At [56].

156 At [56]. 
recover the property it could not be said that he had divested himself of his beneficial ownership of the property.

The test is whether, despite the creation of the arrangement, the settlor can recover the property without the exercise of a power by a "truly independent person". This evaluation of the consequences of the trust deed is unlike the sham doctrine, which relates to the subjective intentions of the parties; it turns on the rights and obligations in the trust deed being an "objective nullity" in the sense of not constituting a valid trust. ${ }^{157}$

Applying this "retention of beneficial ownership" test, the Court of Appeal found that indeed there was no trust. Mr Webb was the sole trustee, and was empowered to exercise his powers and discretions under the trust despite any conflict of interest between his interests and those of the beneficiaries. ${ }^{158}$ As trustee, Mr Webb could appoint himself to the office of "consultant" as set out in the trust deed, as he indeed did. ${ }^{159}$ In that capacity he had powers over investment, the removal and replacement of trustees, consent to acceleration of final vesting and consent to variation of the trust deed. ${ }^{160} \mathrm{As} \mathrm{Mr}$ Webb was also a beneficiary, as trustee he could make distributions of income and/or capital to himself. ${ }^{161}$ If he preferred, he could have also resettled the property on another trust for his own benefit. ${ }^{162}$ As "appointer", he could remove other beneficiaries and make himself the sole beneficiary, collapsing the trust. ${ }^{163}$ The Court also noted that even if he was not the trustee, as consultant Mr Webb could remove or replace the trustees. Because the power was expressed as exercisable "at his absolute discretion and without giving reasons therefore", this was a non-fiduciary power that could be used entirely selfishly. ${ }^{164}$ Although the Court did not conclude that this alone was enough to mean there was no trust, along with the other powers it added "to the picture of a settlor who has never intended to alienate his beneficial interest for the purpose of the law of trusts". ${ }^{165}$ Thus the Court of Appeal concluded that: ${ }^{166}$

157 At [56].

158 At [57].

159 At [59].

160 At [59].

161 At [61].

162 At [62].

163 At [63].

164 At [64].

165 At [64].

166 At [65]. The Court of Appeal's reasoning on this point was upheld by the Privy Council in Webb $v$ Webb (PC), above $\mathrm{n} 12$. The decision was published shortly before this article was finalised. Its reasoning substantially 
... the two deeds of trust fail to record an effective alienation of the beneficial interest in the assets in question. The powers retained by the respondent meant that at any time he could have recovered, and still could recover, the property which he had purported to settle on the trusts. The trusts are therefore invalid.

The Board observed that the Court of Appeal had seen the key question as being "whether, on an objective analysis of the powers reserved to Mr Webb in the trust deeds, Mr Webb had evinced an intention irrevocably to relinquish his beneficial interest in the trust property". ${ }^{167}$ Interestingly, the Board noted that the appellant did not challenge "the proposition that there can be no valid trust if, on the proper interpretation of a trust deed, the settlor has in fact retained beneficial ownership of the property purportedly settled on the trust". ${ }^{168}$ Given the novelty of the ITD, and the practitioner and academic criticism of Birss J's decision in Pugachev on that point (as discussed below), this was a concession of an arguable point. It perhaps also freed the Board from having to consider the ITD in more depth, as the appellant essentially concurred with the "retention of beneficial ownership" test identified and applied by the Webb $v$ Webb Court of Appeal.

It is therefore not surprising that the Privy Council's decision is relatively light on the analysis of why the ITD is a legitimate part of trusts law. The main authorities cited on the point - TMSF and Clayton v Clayton - did not squarely address the ITD question concerning the invalidity of putative trusts. In $T M S F$, the Privy Council considered whether a power of revocation retained by a settlor could be regarded as a right that the settlor should be required to transfer to receivers. ${ }^{169}$ In effect the trust did not protect the settlor from claims against the property they had transferred to it, but the Board did not find that the trust was invalid. Clayton v Clayton, as the Board observed, did not say that the trusts were invalid, but instead found that the powers the settlor held were equivalent to a general power of appointment that fell within the concept of property under the relationship property legislation. ${ }^{170}$ The Board did not refer to Pugachev in its decision.

Indeed, most of the Board's reasoning follows the approach of inquiring into whether the settlor's retained powers allow Mr Webb "to secure the benefit of the trust property to himself". ${ }^{171}$ A number of powers allowed this: (1) the power given to him (as settlor) to remove beneficiaries;

agreed with the Court of Appeal. Therefore, while there are some differences in emphasis and focus, it can essentially be analysed in the same way for the purposes of this article.

167 Webb $v$ Webb (PC), above n 12, at [73].

168 At [76].

169 At [78]. See TMSF, above n 62.

170 At [78].

171 At $[83]$ 
(2) the power, as trustee, to pay capital or income for his personal use; and (3) the power to resettle the trust property on other trusts. ${ }^{172}$

In response, Mr Webb argued that exercising these powers for his own benefit would be a breach of his fiduciary duties as the trustee, ${ }^{173}$ and that interpreting the deed in a way that would allow him to so benefit would be contrary to the trial court's finding that he intended to create valid trusts. ${ }^{174}$ To this, the Board responded that "[a]cceptance that Mr Webb intended to create trusts does not in any way preclude a finding that he reserved such broad powers to himself as settlor and beneficiary that he failed to make an effective disposition of the relevant property." 175 It also observed that Mr Webb's power to remove other beneficiaries was held as settlor, and not in his capacity as trustee or consultant of the trust, which meant they were: ${ }^{176}$

... amply sufficient for Mr Webb to arrange matters in such a way that he alone would hold the trust property on trust for himself and no-one else, with the consequence that the legal and beneficial interest in all of that property would vest in him.

The Privy Council, as noted above, thus effectively adopted the approach of the Webb $v$ Webb Court of Appeal, by focussing on Mr Webb's retention of beneficial ownership over the trust property. However, it distinguished between two approaches. One asks whether the powers retained by the settlor were so extensive that they never disposed of the ostensible trust property. ${ }^{177}$ This was said to be related to the question of whether the "lacked the irreducible core of obligations owed by trustees to the beneficiaries and enforceable by them which is fundamental to the concept of a trust". ${ }^{178}$ This approach is not elaborated on any further, because the Board resolved the case by reference to another approach, which asks "whether the powers reserved to $\mathrm{Mr}$ Webb were so extensive that in equity he can be regarded as having had rights which were tantamount to ownership". ${ }^{179}$ The Board answered this question affirmatively, because "Mr Webb had the power at any time to secure the benefit of all of the trust property to himself and to do so regardless of the interests of the other beneficiaries". ${ }^{180} \mathrm{Mr}$ Webb's deeds therefore failed to

172 At [83]-[85].

173 At [86].

174 At [86].

175 At [87].

176 At [87].

177 At [89].

178 At [89].

179 At [89].

180 At [89]. 
alienate the property, because "[t]he bundle of rights which he retained is indistinguishable from ownership." 181

Webb $v$ Webb shows appellate judges based in New Zealand and England interpreting Cook Islands deeds that putatively (and in the subjective intention of their creators) create a trust, and finding that they do not actually create a trust. There is no suggestion that the trusts law doctrine being applied is special to the Cook Islands. The answer that Webb $v$ Webb gives to the question left open by the New Zealand Supreme Court in Clayton $v$ Clayton is that the illusory trust argument is part of trusts law.

\section{$D$ What is the Rule or Standard to be Applied, and what is its Content Formality?}

If Pugachev and the Webb $v$ Webb decisions signal an acceptance of the ITD, we can expect future illusory trust cases to occupy the courts. The most important practical question then becomes: when will a trust be illusory? This too can be analysed with Atiyah and Summers' concepts of form and substance, this time in relation to content formality. The doctrine would have high content formality if it said that a trust is illusory where: (1) the trustee is exonerated from all personal liability; or (2) can veto certain specified trustee decisions; or (3) if they can distribute all trust property to themselves; (4) or if they have certain specified powers. Those requirements are easily applied simply by looking at the deed. Likewise, it would be simple to advise a person how to avoid the illusory trust danger when settling a trust. Some external regimes take this approach to situations where they will "look through" the trust and treat the trust property as belonging to someone other than the beneficiaries nominated in the trust deed. Other external legal regimes, such as the general anti-avoidance rule in tax, create a look through rule of low content formality, such as general anti-avoidance rules and concepts of "beneficial ownership" that are not clearly specified. What then is the test for whether a trust is illusory, or will be held to be a bare trust for the settlor?

Given the Supreme Court did not decide the point, the rule or standard in Clayton v Clayton is not clear: it seems to support either the reality of control, or meaningful accountability approaches. The lower Courts' statements about the retention of beneficial ownership, which the Supreme Court did not reject, suggest the reality of control approach. However, the lack of meaningful accountability approach seems present in the Supreme Court's emphasis on the way that Mr Clayton could benefit himself and was expressly relieved of the normal fiduciary constraints by a clause of the deed. The Supreme Court thought that such trusts would be rare. This is a rule of fairly high content formality, requiring that key fiduciary obligations to beneficiaries be excluded by the trust deed. This contrasts with the High Court decision, which did not focus on the exclusion of fiduciary obligations. Instead, it looked to the powers of disposition held by the settlor-trustee-beneficiary and the lack of a prohibition on self-benefit; this seems to be the unlimited self-benefit test, even though the judge

181 At [89]. 
spoke in terms of "beneficial ownership". This too has high content formality found in the identification of the powers retained, but it is a very different test and is likely to invalidate far more trusts (at least in New Zealand practice).

The facts in Pugachev have some hallmarks of trustee usurpation, but the decision was decided on the basis of reality of control constituting beneficial ownership: the extensive set of powers, when held by a discretionary beneficiary, are non-fiduciary and mean that the protector has beneficial ownership. The idea of lack of fiduciary restraint from Clayton $v$ Clayton is the same, but in Pugachev the protector did not have the power to make himself the legal owner of the property. He had to rely on a trustee to make that decision. He would not meet the test set out in Webb $v$ Webb (as set out below), which required that he could make himself the legal owner at any time, unless we recognise that Mr Pugachev's ability to veto trustee decisions and to replace the trustee without cause would allow him to add a trustee who was willing to distribute the property to him. That still would require a trustee to make the decision to distribute with consideration of the interests of all beneficiaries. But the trustee would be entitled - indeed required - to take into account the settlor's wishes, and could not be prevented from making the distribution of all the trust's capital to Mr Pugachev. These principles of trusts law support Birss J's view that Mr Pugachev retained beneficial ownership despite not having the ability to make himself legal owner without another person's intervention - because his powers allowed him to select that person and veto their decisions. This idea of the retention of beneficial ownership without specifying any particular set of powers seems to be an ITD of low content formality.

$W e b b v$ Webb represents perhaps the most radical of the decisions in terms of the number of trusts it might invalidate, with the retention of beneficial ownership test suggesting the wide "unlimited selfbenefit" approach to the ITD. While the decisions emphasised the extent of Mr Webb's powers as sole trustee, their statement and application of the law suggest that all that is necessary for a purported trust to be invalid is that it includes clauses that mean that the property can be recovered at any time by the settlor, so that there was no alienation of the beneficial interest. If this is the rule, then any trust where the settlor is the sole trustee and may at any time make a capital distribution to himself is illusory. There is no constraint of fairness that would control the settlor-trustee from taking back what he had settled. Applied to the facts in Webb $v$ Webb, the unlimited self-benefit approach has high content formality as one simply looks to the trustee being a discretionary beneficiary and the lack of effective constraint on the power to benefit oneself. Where there is another trustee, the Courts in Webb $v$ Webb may still have applied the "effective control" test or a sham analysis of the restrictions on the settlor's powers to find the trust was illusory along the lines of Pugachev, as suggested by the language used and the Court's reliance on Pugachev.

The above discussion of the reasoning in the Webb v Webb, Clayton $v$ Clayton and Pugachev decisions demonstrates that courts' discussions of ITD take a variety of approaches, none well justified or explained. It is possible that both the unlimited benefit and effective control tests should be part of the ITD, to apply to both the Clayton/Webb sole trustee-beneficiary and the Pugachev non-trustee 
situations. In Webb $v$ Webb, the Court of Appeal interpreted Clayton $v$ Clayton and Pugachev as illustrating the same general principle: "whether the powers reserved to this respondent-settlor were inconsistent with an intention to irrevocably relinquish a beneficial interest". ${ }^{182}$ Retention of a "beneficial interest" can be found where a settlor-trustee-beneficiary can distribute all of the property to himself without the intervention of another, or where a protector can effectively ensure that the distribution of property they desire will be made due to the powers they hold under the trust. ${ }^{183}$

The lack of detailed reasoning devoted to when a trust will be found to be illusory is therefore an important criticism of the ITD decisions - bar the higher court decisions in Clayton v Clayton that did not need to decide this question. However, the strongest criticisms of the decisions is that they illegitimately place substantive concerns about settlor control over orthodox principles of trusts law. The balance of this article examines such criticisms in light of the form/substantive concepts outlined above, and ultimately finds such criticisms overplayed.

\section{CRITICISM OF THE ITD DECISIONS}

\section{A Criticising the ITD as Contrary to Trusts Law}

Given their prominence as New Zealand Supreme Court and English High Court decisions, there have been strong criticisms of the decisions in Clayton $v$ Clayton and Pugachev. ${ }^{184}$ Pugachev is said to have caused "considerable consternation among practitioners because it is hard to discern anything in the terms of the trusts that took them outside the norm". ${ }^{185}$ On this view, providing powers over the trust to people other than the trustee is a longstanding and useful part of trust law, ${ }^{186}$ subject to the limits of trustee accountability. Thus Birss $\mathbf{J}$ created new legal doctrine where there was none

$182 W e b b v$ Webb (CA), above n 12, at [56].

183 See also the articulation of a test in Thomas Probert "A Lost Opportunity? Omission of the Illusory Trust Doctrine from the Trusts Act 2019" (2019) 50 VUWLR 681.

184 Joel Nitikman "Clayton v Clayton in the New Zealand Supreme Court: it's hard to keep a good court down" (2016) 22 T \& T 1049; Jack Davies "New Developments in Settlor Reserved Powers" [2018] The Conveyancer and Property Lawyer 175; James Brightwell and Luke Richardson "Mezhprom v Pugachev: bold new approach or illusory development?" (2018) 24 T \& T 398; and Gregor Hogan "Mezhprom Bank $v$ Pugachev [2017] EWHC 2426 (Ch)" (2018) 24 T \& T 212.

185 Brightwell and Richardson, above n 184, at 400.

186 Hogan, above n 184, at 214-215; Raymond Davern and Alex Way "An offshore perspective on the 'True Effect' of Mr Pugachev's trusts" (2018) 24 T \& T 406; and Brightwell and Richardson, above n 184, at 398: "The trust instruments themselves were on their face unremarkable ... The findings both that such a document did not create a valid trust on its face and that there was a sham have caused considerable disquiet." 
before. That was the defendant's argument, ${ }^{187}$ and it was accepted by the Court of Appeal in Clayton v Clayton. ${ }^{188}$

From this perspective, if the ITD was a part of trusts law, it would have surely arisen before now. As Anthony Grant observes, given that it may "invalidate large numbers of Trusts you'd expect to find it wrapped in lights in all the leading text books on Trusts - but it isn't." ${ }^{189}$ Indeed, reading most trusts law textbooks, one would get the impression that there is no plausible basis for ITD arguments. The language of the "illusory" trust is used sparingly, and not in relation to settlor control. ${ }^{190}$ The term is used with reference to arrangements that take the form of a trust, but where the "real substance and essence" is another kind of transaction as indicated by the intention that can be gathered from the circumstances of the settlement. ${ }^{191}$ However, this is usually reserved for examples such as a trust for creditors for the payment of a debt or possibly Quistclose trusts. 192

Many textbooks simply do not discuss settlor control as a threat to trust validity, or see it doing so only in the most exceptional circumstances. Similarly, articles discussing the issue often take a very narrow view of the kinds of arrangements that would make a trust invalid, for example situations where (1) the trustees cannot be held to account by the beneficiaries due to the exclusion of liability 193 or the power for someone other than the beneficiaries; or (2) to fully exonerate breaches of trust (both are examples of "insufficient accountability"); ${ }^{194}$ or (3) to veto key trustee decisions ("trustee usurpation"). ${ }^{195}$ Overall, the ITD based on settlor control has little support in the main trusts law textbooks.

187 Pugachev, above n 3, at [156].

188 Clayton v Clayton (CA), above n 11, at [71]-[85], discussed in Pugachev, above n 3, at [157]-[158].

189 Anthony Grant "'Illusory Trusts' - a new doctrine to invalidate Trusts? Part 3" <http://anthonygrant.com>.

190 In contrast, the term "illusory" has been used in the United States to describe the aforementioned problems of settlor control: Newman v Dore 9 NE 2d 966 (NY 1937) at 969. See also Edward A Smith "The Present Status of 'Illusory' Trusts: The Doctrine on Newman v Dore Brought Down to Date" (1945) 44 Mich L Rev 151.

191 Arthur Underhill A Concise Guide to Modern Equity: Being a Course of Nine Lectures (revised and enlarged) (Butterworths, London, 1885) at 142; and Arthur Underhill A Practical and Concise Manual of the Law Relating to Private Trusts and Trustees (3rd ed, Butterworths, London, 1888) at 39.

192 See for example P J Millett "The Quistclose Trust: Who Can Enforce it?" (1985) 101 LQR 269. See also Barclays Bank Ltd v Quistclose Investments Ltd [1970] AC 567 (HL).

193 Armitage v Nurse [1998] Ch 241 (CA).

194 Re AQ Revocable Trusts, above n 126. For a statement of the insufficient accountability view see Jessica Palmer "Controlling the Trust" (2011) 12 OLR 473.

195 Donovan Waters "Settlor control-what kind of problem is it?" (2009) 15 T \& T 12; Christopher McKenzie "Having and Eating the Cake: A Global Survey of Settlor Reserved Power Trusts: Part 1" (2007) 5 PCB 336; and Patrick O'Hagan "The reluctant settlor-proper, powers and pretences" (2011) 17 T \& T 905. See also 
Additionally, the various Courts' attempts to show the validity formality of the ITD - to show that settlor control is a formal reason for decision within trusts law rather than merely a substantive reason - are questionable from the perspective of common law methodology. The recent decisions do cite and discuss some case law, but none of these is a clear authority for the ITD. ${ }^{196}$ Furthermore, none of the decisions spend much time explaining the fundamental principles of trusts law. The Supreme Court in Clayton v Clayton was justified in doing so, as it did not need to decide the issue. This makes more questionable the way that its decision was used as a key authority for the ITD in Pugachev and $W e b b$. And those decisions did not cite the voluminous relevant commentary that does address the ITD in terms of settlor or trustee control in detail.

Given the lack of any real attempt to show a grounding in precedent or basic trusts law principles, there are legitimate questions to be asked about the validity formality of the ITD. From this perspective, the illusory trust cases are legally incorrect according to pre-existing doctrine, and are an attempt to create new limits on trusts. ${ }^{197}$ If accepted, this judicial disregard of the pre-existing legal rules has a negative impact on the predictability and certainty of judicial decisions. ${ }^{198}$ In Atiyah and Summers' terms, this undermines the mandatory formality of trusts law, based on putative substantive reasons against settlor control that do not have any basis in the law - any validity formality. ${ }^{199}$

\section{B The ITD as Therefore Substantivistic}

The critics of the ITD's validity formality will likely also say that the Courts understood this and acted for substantive reasons. In Pugachev the desire to prevent Mr Pugachev from keeping his creditors from claiming against assets he controlled and in Clayton $v$ Clayton and Webb $v$ Webb to ensure that settlor controlled trusts did not defeat relationship property sharing regimes. Along these lines, Professor Charles Rickett has criticised illusory trust decisions as being part of the "shambolic

Conaglen "Sham Trusts", above n 80, at 197: "If the parties truly intended that B would not be held liable in any way for his stewardship of the property then the correct categorisation of the arrangement, as a matter of law, is that it is a gift rather than a trust, despite the parties' mislabelling it."

196 The cases cited concern the irreducible core (Armitage, above n 193); the treatment of a personal power of revocation as property to satisfy the claims of creditors (TMSF, above n 62); and a New Zealand High Court case that considered whether a trust was illusory, but decided it was not (Financial Markets Authority $v$ Hotchin [2012] NZHC 323).

197 Palmer, above n 194, at 393 and 481-484.

198 See the comments on predictability and certainty in Atiyah and Summers, above n 8, at 23-24 and 141-143.

199 Atiyah and Summers, above n 8, at 12: "It is also possible for a reason to have no validity formality at all, as where a decision-maker resorts entirely to reasons of substance not previously recognized in the law." 
state" of the law of trusts in New Zealand, which he sees as motivated by substantivistic (in Rickett's terms, "instrumentalist") reasons for busting trusts: 200

This notion is essentially instrumental in the sense that its very existence is premised upon a need of some sort (not a legally doctrinal need, but a call for the achievement of "fairness" or because of an alleged imperative for social justice) to avoid the consequences of there being in the particular circumstances (of which a number have been discussed in the case law) a trust as opposed to there being no trust. The conceptual beasts either attack the very existence of the apparent trust, not on sound doctrinal grounds but largely through ex post facto policy justifications ...

In addition to Rickett's general critique, Jesse Wall has provided a specific critique of the ITD as depending on substantive (he terms them "functionalist") reasons rather than being an application of the formal law of trusts. ${ }^{201}$ Wall argues that: 202

... recent attempts to further delineate the concept of the illusory trust rely upon a shift from form to function. That is, they require the courts to look beyond the juridical relationship between trustee and beneficiary into the structure of social relations that the trust is giving effect to with regards to the trust property. ... [T] his functionalist turn requires an explanation of why courts should look beyond the juridical form, and more importantly, this functionalist turn necessitates an explanation of the values that inform the functional limits of the concept of the trust.

Wall goes on to question the application of the relevant substantive/functional values that he identifies as grounding the development of the ITD.

Critics of such substantivism might further caution that although trusts law has always been subject to substantive reasons that limit certain uses of trusts that threaten the operation of other external legal areas (creditor rights, feudal incidents, tax), this has been done through statutory interventions that have high validity and mandatory formality. ${ }^{203}$ Such substantive interventions have also often had high content formality; it is clear whether they apply to a particular arrangement. The combination of these features has resulted in the predictability and certainty of trusts law being upheld, allowing the trust to continue to develop as a flexible and secure basis for property management. For courts to now introduce the ITD is to upset the traditional interplay of form and substance -

200 Charles Rickett "Instrumentalism in the Law of Trusts - The Disturbing Case of the Constructive Trust Upon an Express Trust" (2016) 47 VUWLR 463 at 463.

201 Jesse Wall "Taking the Bundle of Rights Seriously" (2019) 50 VUWLR 733 at 749-750.

202 At 749

203 At $743-747$. 
particularly if the test applied has low content formality - with negative consequences for the certainty and predictability of the law. ${ }^{204}$

Critics might also note the seeming importance of substantive reasons in Birss J's long discussion of modern trust practice, with its focus on the motivations and actions of the "unscrupulous person" who wishes to protect assets from creditors without giving up effective control over them. ${ }^{205}$ It is not just critics who see this substantive reason as driving the decision. Akkouh and Lloyd have observed that "[t]he courts are increasingly reluctant to allow defendants to keep assets away from their creditors when they retain de facto control over them", referring to a number of cases where the courts have been careful to prevent trusts being used in this way. ${ }^{206}$ This is the substantive reason for preventing trusts being used to avoid liabilities of ownership.

Similarly, Pey-Woan Lee has accepted the critique that Pugachev is not grounded in formal reasons, but argues that the emphasis on the context - of trusts being used by settlors to divest themselves of legal ownership, thereby avoiding claims of creditors, while retaining control over the property - revealed the substantive reasons that "underpin" the decision. ${ }^{207}$ This prioritising of substantive over formal reasons is not, for Lee, an occasion for criticism in itself; the problem is English courts' failing to recognise their value-laden substantivist reasoning, drawing on morality and policy. ${ }^{208}$

Ultimately, whether courts should prioritise formal reasons or substantive reasons is a philosophical question. The empirical question of how courts actually respond to these reasons is a matter of examining and interpreting their practices. Yet, such substantive reasons are not the basis for the courts' decisions. They are at most secondary in the courts' reasoning, which seek to provide formal reasons for the ITD.

\section{JUSTIFYING THE ITD DECISIONS}

\section{A Uncertainty in Trusts Doctrine}

The above "ITD as substantivism" criticisms also depend on the law of settlor retained powers being clear, and on there being no formal reason within trusts law that could justify the ITD. These points are contestable. The lack of an existing settled ITD does not mean that the judges in Clayton $v$

204 Hogan, above n 184, at 215.

205 Pugachev, above n 3, at [174]-[182].

206 Tim Akkouh and Christopher Lloyd "'Trust-busting' after JSC Mezhdunarodniy Promyshlenniy Bank $v$ Pugachev \& ors [2017] EWHC 2426 (Ch)" (2018) 24 T \& T 151 at 155-156. Akkouh and Lloyd were counsel for the claimants in Pugachev.

207 Lee, above n 5, at 88 .

208 At 93. 
Clayton, Pugachev and Webb $v$ Webb must have simply applied substantive reasons to announce a new legal rule which lacks validity formality and contravening mandatory formality to the detriment of legal certainty. It may be argued that the uncertainty of the law and the novelty of the assertion of the illusory trust argument provided the courts with a legitimate opportunity to settle an unsettled area of the law - and that the reference to what look like substantive reasons relating to beneficial ownership are the application of existing legal concepts of trusts law.

In the first place, we should remember that extreme settlor control is only a recent development in trusts law in the Anglo Commonwealth. In the first half of the 20th century, modern features of trusts law such as massively discretionary trusts and settlor retained powers were uncommon. ${ }^{209}$ Extreme settlor control as trustee-beneficiary or protector is a reasonably new phenomenon, and has often been discouraged by external regimes that give powerful disincentives for holding such control. ${ }^{210}$ The courts have always played "catch up" to the ingenuity of legal practitioners who have dreamed up new structures to achieve advantages for their clients. ${ }^{211}$ There are few cases where the validity of such trusts was argued, and as we have seen, where this point is argued the courts have begun to rule in favour of the ITD. The kinds of trusts that prompt ITD challenges are relatively new, and the recent cases are essentially first impression decisions. Unless the judges in these courts are obviously mistaken, there must be some uncertainty in the law in this area. Indeed, this is the basis for the New Zealand Supreme Court being unable to come to a unanimous view on whether $\mathrm{Mr}$ Clayton's trusts was illusory. ${ }^{212}$

Furthermore, outside of the courts, settlor control has been routinely flagged for caution by trusts law commentators for decades as endangering an arrangement's status as a trust. ${ }^{213}$ Donovan Waters,

209 Donovan Waters "The Trust: Continual Evolution of a Centuries-Old Idea" (2007) 14 JTCP 207; Donovan Waters "The Future of the Trust from a Worldwide Perspective" in David Hayton (ed) The International Trust (3rd ed, Jordan Publishing, Bristol, 2011) 837; and Adam S Hofri-Winogradow "The Stripping of the Trust: A Study in Legal Evolution" (2015) 65(1) UTLJ 1.

210 Bennett, above n 29, at 58.

211 See discussion in Bennett, above n 29.

212 Clayton v Clayton (SC), above n 11, at [126].

213 Lynton Tucker, Nicholas Le Poidevin and James Brightwell Lewin on Trusts (19th ed, Sweet and Maxwell, London, 2014) at [4-031]-[4-032]; James Wadham Willoughby's Misplaced Trust (2nd ed, Gostick Hall Publications, Essex, 2002); Donovan Waters "Trusts: Settlor Reserved Powers" [2006] 25 Est Tr \& Pensions J 234; McKenzie, above n 195; Waters "Settlor control—what kind of a problem is it?", above n 195; Jessica Palmer and Nicola Peart "Clayton v Clayton: A step too far?" (2015) 8 NZFLJ 114; Jeremy Kosky "Sham Trusts and Reserved Powers" in Sara Collins and others (eds) International Trusts Disputes (Oxford University Press, Oxford, 2012); Mark Harper and others International Trust and Divorce Litigation (2nd ed, Jordan Publishing, Bristol, 2013) 23; and Geraint Thomas and David Hayton "Shams, Revocable Trusts, and Retention of Control" in David Hayton (ed) The International Trust (3rd ed, Jordan Publishing, Bristol, 2011) 597. 
a practitioner and academic who experienced the rise of massively discretionary trusts and reserved powers throughout his career, and who has provided much of the scholarly analysis of their history and analysis, expressed concerns about whether these arrangements can be considered trusts, questioning whether "settlor or 'protector' control [presented] a challenge to the fiduciary relationship". ${ }^{214}$ Waters therefore identified a need for: ${ }^{215}$

... a court anywhere within the common law Commonwealth that is called upon to analyze and rationalize

what can and what cannot be done. As it is, onshore case law on the subject is almost non-existent, save

for time-honoured precedents from earlier decades that distinguish trust and agency ...

It might be said that the recent ITD decisions have given one view of what can be done, but perhaps with insufficient analysis.

If it is accepted that extreme settlor control is relatively novel and the law therefore uncertain, the next question is what aspect of trusts law doctrine causes the uncertainty. One view is that the existence of a trust is called into question where the trustee is able to take the whole benefit of the property that he/she is ostensibly holding for the benefit of others. For such a person seems not to be a true fiduciary or trustee ("unlimited benefit"). The other view sees a person who, because of their position under the trust (for example as trustee and discretionary beneficiary, or as protector and discretionary beneficiary) and the legal powers they hold under it (for example, to add and remove trustees, or to veto trustee decisions), as having effective control or beneficial ownership of the trust property under a bare trust ("beneficial ownership"). While these wider views are not prominent in the textbooks, they are often considered in the context of noting the uncertainty of the limits of settlor or protector control.

The basis for these wider views is the doctrinally important idea that a trust must place fiduciary obligations on the trustee to hold the trust property for the benefit of the nominated beneficiaries. This idea creates doubts for settlor - or protector - controlled trusts, for how can a person be a fiduciary for others when they have the ability to put their own interests first? Where someone other than the trustee holds non-fiduciary powers to veto key trustee discretions and to replace the trustee, and is also a nominated beneficiary, it is arguable that the trust seems more of a bare trust for that person than a discretionary trust for the beneficiaries. Commentators such as Tobias Barkley and Lionel Smith have argued that a trustee fiduciary cannot have the power to distribute all the property to himself while remaining a trustee. ${ }^{216}$ Even Lewin on Trusts sees fiduciary self-benefit as a "problem",

214 Waters "Settlor control—what kind of a problem is it?", above n 195, at 17.

215 Waters "Trusts: Settlor Reserved Powers", above n 213, at 266.

216 Tobias Barkley "Clayton v Clayton: The Court of Appeal on the Concepts of Property and Trusts" [2015] NZLJ 164; Tobias J Barkley "The content of the trust: what must a trustee be obliged to do with the property?" (2013) 19 T \& T 452; Lionel Smith "Mistaking the Trust" (2010) 40 HKLJ 787 at 790-791; and Lionel Smith 
particularly where it is dispositive self-benefit. ${ }^{217}$ It therefore cannot be said that there is no doctrinal foundation - validity formality - for the ITD, for the unlimited self-benefit that characterises illusory trusts is arguably part of the very idea of the fiduciary relationship central to express trusts.

\section{$B$ The ITD as a Legitimate Development}

If it is accepted that that there are doctrinal sources within trusts law for the ITD, it is therefore arguable that Pugachev and Webb v Webb sit within the bounds of the development of judge made law in the common law tradition and that the ITD thereby has adequate validity formality, rather than being an instance of substantivism. The uncertainty about the concept reflects an aspect of the common law that Atiyah and Summers observe: its validity formality is lower than statute, which leads to some uncertainties about the role of formal and substantive reasons in its development:218

Common law judges often find it unnecessary to draw a clear line between what ought to be and what is. On the one hand, change is glossed over, if not obscured altogether, by the judicial tendency... to claim that a new decision does not really amount to a change at all. On the other hand, the judge may advance reasons of substance for what the law ought to be, and then render a decision stating that the law already is what it ought to be. The result is that it is often unclear whether the judges are spelling out the reasons of substance embedded in the formal law involved, or truly changing the law.

To say that the narrow view is the settled law and that courts cannot develop trust law to include the ITD is formalistic in not recognising the unsettled nature of the law and the need for matters of substance to be considered in the development of the common law. ${ }^{219}$

Another claim of the critics - that trusts lawyers know better than the judges, as they are those who develop the flexible institution of the trust through their structuring of people's private affairs can be countered by another observation of Atiyah and Summers. They say that one of the second order normative reasons to favour the use of formal over substantive reasoning is that someone has already considered the relevant substantive reasons and made the decision to create the formal rules as the proper resources for decision-making in the particular area. ${ }^{220}$ Where that has not occurred, such as where there is a new legal or social development that has not been made with a balanced reflection of the substantive reasons at stake, then "to make the decision by purely formal reasoning is to shut out the possibility of that decision ever being based on the factors most directly relevant to

"Can We Be Obliged to be Selfless" in Andrew S Gold and Paul B Miller (eds) Philosophical Foundations of Fiduciary Law (Oxford University Press, Oxford, 2014) 156.

217 Tucker, Le Poidevin and Brightwell, above n 213, at [20-166] and [20-168].

218 Atiyah and Summers, above n 8, at 148 .

219 At $28-29$.

220 PS Atiyah "Form and Substance in Contract Law" Essays on Contract (Oxford University Press, New York, 1990) 93 at 118-119; and Atiyah and Summers, above n 8, at 22. 
it". 221 If lawyers have pushed the envelope with settlor control trusts, without adequately considering the effect of this on trustees' fiduciary obligations, then the formal reasons suggested by such trust deeds cannot be left immune from the court's scrutiny according to basic principles of trusts law. ${ }^{222}$

\section{The Courts' Self-Understanding}

Thus the idea that the courts are acting in a substantivistic manner by recognising the legal consequences of such control can be rebutted in the abstract. The criticism of substantivism could still sting, however, if the courts reasoned in an illegitimately substantive way (compared to the accepted formal common law interpretive methodology). ${ }^{223}$ However, as Brightwell and Richardson observe of Pugachev: "[t]he judgment is undoubtedly perceived to have broken new ground yet purported to apply established case law concerning the circumstances where a settlor has not created a valid trust". ${ }^{24}$ Likewise, the judges in each of the recent ITD decisions claim a formal basis for their argument in basic principles of trusts law, rather than substantive reasons that cannot be found in the existing law.

In Clayton v Clayton, the lower Courts and the Supreme Court focussed on the question of whether the settlor had divested himself of the powers of ownership or control over the property sufficient to create a trust. The lower Courts referred to basic principles of trust law, and cited cases in support of their decisions. ${ }^{225}$ While this links with the substantive reasons underlying trust law and external regimes that impose liability on ownership, the Courts did not take themselves as responding directly to those reasons, but to fundamental principles of trusts law. In Pugachev the decision focussed on Clayton v Clayton as a precedent stating the relevant principles. Subsequently, the Court of Appeal in $W e b b v W e b b$ was able to point to both of these cases as authority.

Apart from the Supreme Court in Clayton v Clayton, none of the Courts framed its task as settling an unsettled legal question by reference to substantive considerations. ${ }^{226}$ While this suggests the other Courts took themselves to be reasoning within the bounds of appropriate common law approach validity formality, it also demonstrates a major omission from these decisions. As the Supreme Court observed and the commentary literature demonstrates, settlor control of trust and the ITD are not

221 Atiyah, above n 220, at 119. See also Atiyah and Summers, above n 8, at 37.

222 Such an argument is made generally in Bennett, above n 29; and Bennett and Hofri-Winogradow, above n 41.

223 Atiyah and Summers, above n 8, at 118 and following. See also Schauer, above n 19, at ch 8; and Ben McFarlane "Modern Equity - At the Edge of Formal Reasoning?" in Andrew Robertson and James Goudkamp (eds) Form and Substance in the Law of Obligations (Hart Publishing, Oxford, 2019) 197 at 221-222.

224 Brightwell and Richardson, above n 184, at 398.

225 The Family Court cited Armitage, above n 193; and TMSF, above n 62. The High Court cited Financial Markets Authority v Hotchin, above n 196.

226 Atiyah and Summers, above n 8, at 19 and 22. 
settled law. Pugachev, Webb v Webb and the lower Courts in Clayton v Clayton failed to acknowledge the "nascent and fragmentary character"227 of the law in this area, which should lead a court to provide a comprehensive analysis of the prior precedent, ${ }^{228}$ and to consider the substantive reasons that apply to the law. 229

\section{CONCLUSION}

The ITD places internal limits on what can be done with trusts in terms of settlor control. As this article shows, this need not be interpreted as a flight from formal legal rules to extralegal substance. In other words, interpreted as simply the courts responding to substantive reasons of countering the plans of "unscrupulous persons" who wish to divest themselves of ownership of property while retaining control and the ability to benefit from it. Such critical accounts can be challenged due to the arguable grounding of the ITD in such principles of trust law, which can be seen in the uncertainty about the consistency of settlor control with the idea of trusts as containing fiduciary obligations to the nominated beneficiaries. The courts have focussed on these, rather than substantive reasons, in articulating the basis for the ITD.

However, their decisions have not grappled with these basic principles or the (admittedly meagre) authority discussing them, or the more well-developed scholarly and textbook literature on these issues. Further, in developing the ITD, the courts have not articulated clear tests for when "a trust is not a trust". The future jurisprudence on illusory trusts should therefore focus on the analysis of the basic principles of trusts law, and determine whether the idea of fiduciary obligations to nominated beneficiaries is sufficiently undermined by settlor powers and roles to mean that no trust has been created.

All of that would proceed within the bounds of formal legal reasoning, rather than depending on substance. But courts should also bear in mind Atiyah and Summers' criticism of formalistic reasoning, which excludes substantive reasons from novel cases where it is appropriate to consider substantive reasons. ${ }^{230}$ They should also therefore consider the "substance over form" approach, particularly its application to settlor-controlled trusts that are used to subvert the policies of other areas of law ${ }^{231}$ - as a substantive reason to add to the consideration of the aforementioned formal reasons of existing trusts law.

\section{At 28.}

228 At 50-51. Atiyah and Summers note that English courts operate a more formal standard of validity for common law rules than the content-oriented (substantive) practice in the United States.

229 At 28 .

230 At $28-29$.

231 See above Part III; and Bennett and Hofri-Winogradow, above n 41. 